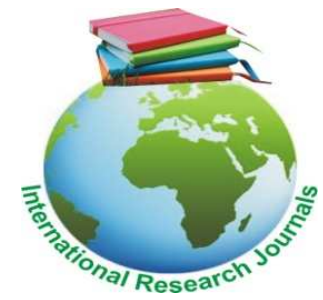

International Research Journal of Agricultural Science and Soil Science (ISSN: 2251-0044) Vol. 7(3) pp. 046-050, October, 2017

Available online http://www.interesjournals.org/IRJAS

DOI: http:/dx.doi.org/10.14303/irjas.2017.054

Copyright (C) 2017 International Research Journals

Full Length Research Paper

\title{
Yield evaluation of yellow cassava varieties as affected by inorganic fertilizer in two agro ecological zones of Nigeria
}

\author{
*Olaiya A.O and Salami A. O. \\ ${ }^{1}$ Federal University of Agriculture Abeokuta \\ ${ }^{2}$ Afe Babalola University Ado Ekiti \\ *Corresponding Author's E-mail: salamio@abuad.edu.ng
}

\begin{abstract}
Field experiment was conducted at the International Institute of Tropical Agriculture Ibadan and Ikene substation during the 2012 rainy season to study the effect of variety and Crystallizer fertilizer on the yield of four yellow cassava varieties. Four (4) IITA yellow cassava varieties (IITA TMS 01/1368, IITA TMS 01/1371 and IITA TMS01/1412 and IITA TMS 01/1593), were tested at three different rates (0 kgha ${ }^{-1}, 400$ $\mathrm{kgha}^{-1} \mathrm{~kg} / \mathrm{ha}$ and $600 \mathrm{kgha}^{-1}$ ) in split plot fitted to RCBD. Data collected on yield parameters were analyzed using ANOVA and means were separated with Least Significant Difference. The varieties TMS01/1371 and TMS01/1412 significantly $(P \leq 0.05)$ produced highest fresh tuber yield of $\left(9.33\right.$ tonsha $\left.{ }^{-1}\right)$ and (8.99tonsha $\left.{ }^{-1}\right)$ at Ibadan and Ikene respectively. The variety TMS 01/1593 significantly $(P<0.05)$ produced highest dry matter content $(35.50 \%)$ and total carotene value $(7)$ of all the yellow cassava varieties in Ibadan. It was concluded, that since the variety TMS01/1593 produced highest total carotene content $(7.00)$ and dry matter content $(35.50 \%)$, it can therefore be recommended for cultivation and consumption in lbadan to increase the quantity of cassava products and enhance vitamin $A$ intake. Since TMS01/1371 produced the highest fresh tuber yield of $\left(9.33\right.$ tonsha $\left.^{-1}\right)$ without the application of Crystallizer fertilizer in Ibadan, it can be cultivated in Ibadan to obtain 9.33tonsha ${ }^{-1}$ fresh. A further research is recommended to determine the rates of Crystallizer fertilizer to increase yields obtainable in both locations.
\end{abstract}

Keywords: Yellow cassava, total carotene, fresh tuber yield, crystallizer fertilizer

\section{INTRODUCTION}

Cassava is a major staple food crop of the people in most parts of Africa, plays an important role in terms of food security, employment and income generation for farm families in parts of the humid tropics. It derives its importance from the fact that it produces more calories/unit area from its starchy tuberous root which is a valuable source of cheap calories especially in developing countries (Som, 2007). The crop contributes significantly to the economy of most tropical countries (Amani et al., 2005; Kawano et al., 2003). The edible root supplies energy for more than 500 million people worldwide (Ceballos et al., 2006) and it can be processed into various products and industrial applications (Abu et al., 2006; Ceballos et al., 2006). The land holding for farming in Nigeria is between 0.5-2.5 hectares (1.2-6.2 acres), with about $90 \%$ of producers being small-scale farms (Adeniji et al., 2005).

Cassava has earned the reputation of being well adapted to soils of low fertility. This stems from its ability to produce some yield, however low, in subsistence agricultural systems on soils of low fertility status and this has contributed greatly to its success over other staple food crops. For this reason, peasant farmers do not fertilize cassava as they are contented with the minimal yield obtained from using limited inputs from their poor soils. However farmers rarely use chemical fertilizer due 
to scarcity and cost, hence the dependence on cheap organic sources of nutrients.

One of the most important factor limiting yields in African agricultural system is low soil fertility. The low fertility of soil has made it possible for food production to be at pace with the population growth in sub-Saharan Africa. Although, cassava adapts to low fertility of the soil, the soil is the most important limiting factor essential for agricultural production in the humid tropics (Okigbo, 1989). Fertilizer recommended rate of $400 \mathrm{~kg}$ per hectare have been reported by (Ibia and Udo, 2009) in order to increases the yield of cassava

In many regions of the world over $30 \%$ of the population have insufficient calories in their diet to meet their nutritional needs. By 2020, the FAO has estimated that one billion persons will be undernourished or receive insufficient calories in their diet. Nowhere is this problem more severe than in sub-Saharan Africa. In addition to receiving insufficient calories in the diet, many subsistence farmers depend on a single staple crop for most of their calories. Some of these staple crops may not provide a balanced or complete supply of micronutrients and vitamins leading to malnutrition. These reasons necessitate research on increasing effectiveness of inorganic fertilizers and suitable rate of application.

Thus, the proper level of fertilization and the correct balance of nutrient applied are of utmost importance if cassava is to be elevated from poverty alleviator to industrial crop.

\section{MATERIALS AND METHODS}

The field experiment was conducted during the $2012 / 2013$ growing season in two experimental fields of the International Institute of Tropical Agriculture (IITA) Ibadan Oyo state Nigeria, located at latitude $73^{\circ} \mathrm{N}$ and longitude $345^{`} \mathrm{E}$, in the forest-Savannah agro ecology and International Institute of Tropical Agriculture (IITA) substation lkene located at 6 $6^{\circ} \mathrm{N}$ and longitude $37^{\prime} \mathrm{N}$ in the humid forest agro ecology. The annual rainfall at Ibadan was $1312 \mathrm{~mm}$ with annual temperature ranging from $20.3 \mathrm{C}$ o to $33.8 \mathrm{C}$ while that of Ikene was $1200 \mathrm{~mm}$, with annual temperature ranging from $27^{\circ} \mathrm{C}$ to $35 \mathrm{C}$. The soil of the study sites was loamy sand.

The experiment in both locations was $2 \times 3 \times 4$ factorial established in a split split-plot, with three replications. Crystallizer fertilizer was applied at three different rates of $0 \mathrm{~g}$ per plant for $0 \mathrm{kgha}^{-1}, 40 \mathrm{~g}$ per plant for $400 \mathrm{kgha}^{-1}$ and $60 \mathrm{~g}$ per plant for $600 \mathrm{kgha}^{-1}$ on four IITA improved yellow cassava varieties, IITA-TMS01/1368, IITA-TMS01/1371, IITA- IITATMS01/ 1412 and TMS01/1593. The total number of treatments was 24. Fertilizer type used was Crystallizer which was placed in the main plot, the three (3) rates were assigned to the sub-plot, while the 4 varieties were assigned randomly to the sub-subplot, with
3 replications. Data were collected on the 4 middle inner rows (net plot) leaving out the first and last plants on the ridges to eliminate boarder effect. Weeds were controlled using manual hoe weeding. Recommended cuttings of 25 centimeter $(\mathrm{cm})$ of these varieties were cut and planted at a spacing of $1 \mathrm{~m} \times 1 \mathrm{~m}$ in an inclined position. The fertilizer was measured according to the required rate per sub-plot using an electronic sensitive scale and applied once at 8 weeks after planting.

The fertilizer was applied in a whole approximately 5$6 \mathrm{~cm}$ deep and about $10 \mathrm{~cm}$ away from the root of the plant and covered. Soil samples were collected using a soil augur from each sub-plot using the simple random sampling method. The plants were harvested at 12MAP; all the plots were harvested on the same day in the early morning hours from $8: 00$ to $10: 00 \mathrm{~h}$, this is to avoid differences in moisture content. Data taken at harvest includes fresh tuber yield, number of tubers, dry matter content and total carotene.

The root dry matter content (DMC) was determined from a random sample of three roots taken from each sub-sub plot from all replications. The samples were thoroughly washed to remove the soil attached to it, the samples were shredded and $100 \mathrm{~g}$ sample was weighed and oven-dried at $70{ }^{\circ} \mathrm{C}$ for $48 \mathrm{hr}$. The percentage of DMC was calculated as the ratio of the dry weight multiplied by 100 over the fresh weight.

\section{RESULT AND DISCUSSION}

The result revealed that TMS 371 recorded the highest fresh tuber yield (9.33tonsha ${ }^{-1}$ ) with $400 \mathrm{kgha}^{-1}$ at lbadan while TMS 368 gave the lowest fresh tuber yield of $\left(3.67\right.$ tonsha $^{-1}$ ) with $600 \mathrm{kgha}^{-1}$ Crystallizer fertilizer also at Ibadan.

The results shows a significant increase in the fresh tuber yield of all the yellow cassava varieties except TMS 593 as fertilizer rates increased from 400-600 kgha-1 in Ikene. (Agbaje and Akinlosotu, 2004) reported that Crystallizer fertilizer NPK 15:15:15 did not significantly improve the root yield of cassava in early planted cassava.

The dry matter content of all cassava varieties studied varied as fertilizer rates were increased, the highest dry matter content was recorded by TMS 593 (35.50\%) in Ibadan while TMS 371 recorded the lowest dry matter content of $14.70 \%$ at Ikene. A significant reduction in dry matter content of TMS 593was observed as Crystallizer fertilizer was increased to $400 \mathrm{kgha}^{-1}$

Dry matter content of cassava is affected by a number of factors such as age of plant, season, location of planting and variety. The dry matter contents for the four cassava varieties were at the high range of values as corroborated by (Chávez et al., 2005) who screened roots from 2,457 genotypes, comprising landraces and improved clones, for their nutritional and agronomic traits. 
048 Int. Res. J. Agric. Sci. Soil Sci.

Table 1: Interaction effects of fertilizer type $\mathrm{x}$ rates $\mathrm{x}$ varieties on fresh tuber yield (tons/ha) of cassava varieties in Ibadan and Ikene

\begin{tabular}{|c|c|c|c|c|c|c|}
\hline \multirow[b]{2}{*}{ Rates $\left(\mathrm{kgha}^{-1}\right)$} & \multicolumn{3}{|c|}{ Ibadan } & \multicolumn{3}{|c|}{ Ikene } \\
\hline & 0 & 400 & 600 & 0 & 400 & 600 \\
\hline \multicolumn{7}{|l|}{ Varieties } \\
\hline TMS 412 & 5.99 & 5.99 & 5.99 & 6.33 & 8.66 & 8.99 \\
\hline TMS 368 & 5.33 & 5.33 & 3.67 & 4.33 & 5.99 & 6.99 \\
\hline TMS 371 & 9.33 & 9.33 & 6.33 & 5.99 & 6.99 & 7.66 \\
\hline TMS 593 & 8.33 & 8.33 & 7.33 & 4.33 & 7.99 & 7.58 \\
\hline
\end{tabular}

$\mathrm{LSD}=0.28$

Table 2: Interaction effects of fertilizer type $x$ rates $x$ varieties on dry matter content (\%) of cassava varieties in Ibadan and lkene

\begin{tabular}{lcccccc}
\hline Rates (kgha & - $)$ & Ibadan & & \multicolumn{3}{c}{ Ikene } \\
Varieties & $\mathbf{0}$ & $\mathbf{4 0 0}$ & $\mathbf{6 0 0}$ & $\mathbf{0}$ & $\mathbf{4 0 0}$ & $\mathbf{6 0 0}$ \\
TMS 412 & & & & & & \\
TMS 368 & 23.30 & 26.40 & 20.20 & 24.80 & 19.40 & 28.50 \\
TMS 371 & 28.30 & 25.30 & 21.50 & 26.70 & 25.80 & 35.30 \\
TMS 593 & 24.30 & 34.10 & 22.90 & 21.00 & 23.70 & 14.70 \\
\hline
\end{tabular}

$\mathrm{LSD}=5.39$

Table 3: Interaction effects of fertilizer type $x$ rates $x$ varieties on number of tubers/stand of cassava varieties in Ibadan and Ikene.

\begin{tabular}{lcccccc}
\hline & \multicolumn{3}{c}{ Ibadan } & & \multicolumn{3}{c}{ Ikene } \\
Rates $\left(\right.$ kgha $\left.^{-\mathbf{1}}\right)$ & $\mathbf{0}$ & $\mathbf{4 0 0}$ & $\mathbf{6 0 0}$ & $\mathbf{0}$ & $\mathbf{4 0 0}$ & $\mathbf{6 0 0}$ \\
\hline Varieties & & & & & & \\
TMS 412 & 19.00 & 14.00 & 16.00 & 13.00 & 12.00 & 10.00 \\
TMS 368 & 20.00 & 17.00 & 22.00 & 20.00 & 18.00 & 16.00 \\
TMS 371 & 20.00 & 11.00 & 15.00 & 13.00 & 42.00 & 9.00 \\
TMS 593 & 15.00 & 15.00 & 10.00 & 10.00 & 12.00 & 12.50 \\
\hline
\end{tabular}

$\mathrm{LSD}=3.98$

Dry matter contents of their research recorded values ranging from $14.7 \%$ to $57.2 \%$, with an average of $33.5 \%$.

The number of tubers of cassava varieties varied as fertilizer rates were increased as TMS 368 recorded the highest number of tubers (22.00) while TMS 371 gave the lowest number of tubers of (9.00) at lkene.

The total carotene content of all the cassava varieties did not show any significant difference as fertilizer rates were varied as the variety effect was highly significant and fertilizer type and rate did not significantly affect the total carotene content of all the cassava varieties. Although TMS 593 recorded the highest carotene content irrespective of fertilizer type and rate, TMS 412 recorded the lowest carotene value irrespective of fertilizer, rate and location.
The results obtained does not support the hypothesis that total carotene value of cassava is affected by fertilizer application but that variety has an influence on the total carotene composition of cassava roots. This could be attributed to the fact that the variety is known for its high beta-carotene content (Norbert et. al., 2012). The total carotene content of each variety was the same as fertilizer rates increased for each fertilizer type in both locations. The intensity of the root colour has been shown to be highly correlated with carotene content making it feasible to use visual selection for colour intensity in improvement of carotene content (Iglesias et al., 1997).

In terms of root size of cassava varieties, three varieties namely TMS 412, TMS 371 and TMS 593 recorded the highest root sizes in Ibadan, although TMS 
Table 4: Interaction effects of fertilizer type $x$ rates $x$ varieties on total carotene of cassava varieties in Ibadan and lkene

\begin{tabular}{|c|c|c|c|c|c|c|}
\hline \multirow[b]{2}{*}{ Rates $\left(\mathrm{kgha}^{-1}\right)$} & \multicolumn{3}{|c|}{ Ibadan } & \multicolumn{3}{|c|}{ Ikene } \\
\hline & 0 & 400 & 600 & 0 & 400 & 600 \\
\hline \multicolumn{7}{|l|}{ Varieties } \\
\hline TMS 412 & 4.00 & 4.00 & 6.00 & 5.00 & 5.00 & 5.00 \\
\hline TMS 368 & 4.00 & 4.00 & 4.00 & 6.00 & 6.00 & 6.00 \\
\hline TMS 371 & 6.00 & 6.00 & 6.00 & 6.00 & 6.00 & 6.00 \\
\hline TMS 593 & 7.00 & 6.00 & 4.00 & 7.00 & 6.00 & 4.50 \\
\hline
\end{tabular}

$\mathrm{LSD}=1.74$

Table 5: Interaction effects of fertilizer type $\mathrm{x}$ rates $\mathrm{x}$ varieties on root size of cassava varieties in Ibadan and Ikene

\begin{tabular}{lcccccc}
\hline & \multicolumn{5}{c}{ Ibadan } \\
Rates $\left(\mathbf{k g h a}^{\mathbf{- 1}} \mathbf{)}\right.$ & $\mathbf{0}$ & $\mathbf{4 0 0}$ & $\mathbf{6 0 0}$ & $\mathbf{0}$ & $\mathbf{4 0 0}$ & $\mathbf{6 0 0}$ \\
\hline Varieties & & & & & & \\
TMS 412 & 7.00 & 7.00 & 3.00 & 5.00 & 7.00 & 7.00 \\
TMS 368 & 3.00 & 5.00 & 3.00 & 5.00 & 5.00 & 7.00 \\
TMS 371 & 5.00 & 5.00 & 3.00 & 5.00 & 5.00 & 7.00 \\
TMS 593 & 7.00 & 7.00 & 3.00 & 5.00 & 5.00 & 7.00 \\
\hline
\end{tabular}

$\mathrm{LSD}=1.80$

412 gave the highest root size in Ikene. A significant decrease in root size was observed for all the cassava varieties when fertilizer rate was applied up to $600 \mathrm{kgha}^{-1}$. A similar result where fertilizer application reduced root size of cassava has been reported by (Agbaje and Akinlosotu, 2004)

\section{CONCLUSION}

The results obtained from the experiments were able to detect varietal effects on the fresh tuber yield, total carotene content and dry matter content of yellow cassava varieties. Fertilizer type and rate of application did not significantly influence the fresh tuber yield and total carotene content of yellow cassava. It can be concluded that since the variety TMS01/1593 produced highest total carotene content (7.00) and dry matter content $(35.50 \%)$, it can therefore be recommended for cultivation and consumption in Ibadan to increase the quantity of cassava products and enhance vitamin A intake. Since TMS01/1371 produced the highest fresh tuber yield of (9.33tonsha ${ }^{-1}$ ) without the application of Crystallizer fertilizer in Ibadan, it can be cultivated in Ibadan to obtain 9.33 tonsha ${ }^{-1}$ fresh. A further research is recommended to determine the rates of Crystallizer fertilizer to increase yields obtainable in both locations.

\section{ACKNOWLEDGMENTS}

We wish to appreciate the International Institute of Tropical Agriculture (IITA), Ibadan Headquarters, Nigeria, for the support and assistance given to us to carry out this research work in their lbadan plots and lkene substation.

\section{REFERENCES}

Adeniji AA, Ega LA, Akoroda MO, Adeniyi AA, Ugwu BO, Balogun A (2005). Cassava Development in Nigeria. Depart. Agric. Federal Ministry of Agric. and Natural Resources Nigeria. FAO.

Agbaje GO, Akinlosotu TA (2004). Influence of NPK fertilizer on tuber yield of early and late-planted cassava in a forest alfisol of southwestern Nigeria. African J. Biotech., 3(10): $547-551$

Amani NG, Kamenan A, Rolland-Sabate A, Colonna P (2005). Stability of yam starch gels during processing. African J. Biotech., 4(1): 94101

Ceballos H, Sanchez T, Morante N, Fregene M, Dufour D, Smith A, Denyer K, Perez J, Calle F, Mestres C (2006). Discovery of an Amylose-free starch mutant in cassava (ManihotesculentaCrantz). J. Agric. and Food Chem. 55: 7469-7476.

Chavez JP, Petrie R, Roth M (2005). Farm household production efficiency: Evidence from the Gambia. American J. Agric. Econ. 87 (1):160-179.

Ibia TO, Udo EJ (2009). Guide to fertilizer use for crops in Akwa Ibom State, Nigeria. Sibon Books Limited. Festac, Lagos. p. 43.

Iglesias C, Mayer J, Chavez L, Calle F (1997). Genetic potential and stability of carotene content in cassava roots. Euphytica 94:367-373. 
050 Int. Res. J. Agric. Sci. Soil Sci.

Kawano K (2003). Thirty years of cassava breeding for productivity: biological and social factors for success. Crop Sci. 43: 1325-1335.

Norbert M, Parkes E, Peter AK, Simone KF, Schweigent A (2012). Quantification of total carotene content of yellow root cassava genotypes using the Check TM carotene in comparison with the standard spectrophotometer method. IITA Ibadan.

Okigbo BN (1989). Development of sustainable agricultural production systems in Africa. Distinguished African scientist lecture series April 26, IITA Ibadan, Nigeria

Som D (2007). Handbook of Horticulture, Indian Council of Agricultural Res., New Delhi, pp501-504. 